\title{
Nature, Density, and Catalytic Role of Exposed Species on Dispersed $\mathrm{VO}_{x} / \mathrm{CrO}_{x} / \mathrm{Al}_{2} \mathrm{O}_{3}$ Catalysts
}

\author{
Shuwu Yang, Enrique Iglesia,* and Alexis T. Bell* \\ Chemical Sciences Division, Lawrence Berkeley National Laboratory, and Department of Chemical \\ Engineering, University of California, Berkeley, California 94720-1462
}

Received: September 14, 2005

\begin{abstract}
The structure and surface composition of binary oxides consisting of $\mathrm{CrO}_{x}$ and $\mathrm{VO}_{x}$ dispersed on alumina and their effects on the rate and selectivity of oxidative dehydrogenation (ODH) of propane were examined and compared with those for $\mathrm{CrO}_{x}$ and $\mathrm{VO}_{x}$ dispersed on alumina. $\mathrm{VO}_{x}$ deposition on an equivalent $\mathrm{CrO}_{x}$ monolayer on alumina and deposition of $\mathrm{CrO}_{x}$ on an equivalent monolayer of $\mathrm{VO}_{x}$ deposited on alumina led to $\mathrm{CrVO}_{4}$ species during thermal treatment with concomitant reduction of $\mathrm{Cr}^{6+}$ to $\mathrm{Cr}^{3+}$. Autoreduction of $\mathrm{Cr}^{6+}$ to $\mathrm{Cr}^{3+}$ is also detected for $\mathrm{CrO}_{x}$, even without the presence of $\mathrm{VO}_{x}$. Infrared spectroscopy of NO adsorbed at $153 \mathrm{~K}$ probes the relative abundance of alumina and of $\mathrm{V}^{5+}, \mathrm{Cr}^{3+}$, and $\mathrm{Cr}^{6+}$ at surfaces. This technique detects differences in the surface composition of $\mathrm{VO}_{x} / \mathrm{CrO}_{x} / \mathrm{Al}_{2} \mathrm{O}_{3}$ and $\mathrm{CrO}_{x} / \mathrm{VO}_{x} / \mathrm{Al}_{2} \mathrm{O}_{3}$. The first of these samples is enriched in $\mathrm{VO}_{x}$ relative to $\mathrm{CrO}_{x}$ compared with the second sample. Consistent with this finding, $\mathrm{VO}_{x} / \mathrm{CrO}_{x} / \mathrm{Al}_{2} \mathrm{O}_{3}$ and $\mathrm{CrO}_{x} / \mathrm{VO}_{x} / \mathrm{Al}_{2} \mathrm{O}_{3}$ are distinguishable in their ODH activities and propene selectivities. The highest ODH activity and propene selectivity is observed for $\mathrm{VO}_{x} / \mathrm{CrO}_{x} / \mathrm{Al}_{2} \mathrm{O}_{3}$, which exhibits a surface enriched in $\mathrm{VO}_{x}$ and having a low surface concentration of $\mathrm{Cr}^{6+}$.
\end{abstract}

\section{Introduction}

$\mathrm{VO}_{x} / \mathrm{Al}_{2} \mathrm{O}_{3}$ is one of the most active and selective catalysts reported for the oxidative dehydrogenation $(\mathrm{ODH})$ of propane to propene ${ }^{1-25}$ but reaction rates and selectivities remain too low for industrial practice. $\mathrm{V}-\mathrm{O}-\mathrm{Al}$ linkages present in $\mathrm{VO}_{x} /$ $\mathrm{Al}_{2} \mathrm{O}_{3}$ are relatively inactive for $\mathrm{ODH}$ reactions but favor secondary combustion of propene to $\mathrm{CO}$ and $\mathrm{CO}_{2} \cdot{ }^{11,26}$ These undesired $\mathrm{V}-\mathrm{O}-\mathrm{Al}$ linkages can be minimized by placing an intervening layer of another reducible oxide between $\mathrm{VO}_{x}$ and $\mathrm{Al}_{2} \mathrm{O}_{3}{ }^{26,27}$ Specific promotional effects were detected when $\mathrm{CrO}_{x}$ was used as the intervening layer. ${ }^{27} \mathrm{VO}_{x} / \mathrm{CrO}_{x} / \mathrm{Al}_{2} \mathrm{O}_{3}$ $(\mathrm{VCrAl})$ gave higher propene rates than $\mathrm{VO}_{x} / \mathrm{Al}_{2} \mathrm{O}_{3}$; preliminary studies showed that the bilayer structure was disrupted during thermal treatment, leading to partial mixing of $\mathrm{VO}_{x}$ and $\mathrm{CrO}_{x}$ layers, with the resulting formation of $\mathrm{V}-\mathrm{O}-\mathrm{Cr}$ linkages and with significant uncertainty about the extent to which $\mathrm{VO}_{x}$ and $\mathrm{CrO}_{x}$ species were exposed at catalytic surfaces. ${ }^{27}$ Both $\mathrm{Cr}^{3+}$ and $\mathrm{Cr}^{6+}$ were detected in $\mathrm{VO}_{x} / \mathrm{CrO}_{x} / \mathrm{Al}_{2} \mathrm{O}_{3}$, and it seemed that $\mathrm{Cr}^{6+}$ favored the primary combustion of propane, which led to low propene selectivity. Thus, there is a need to characterize the surface composition of mixed metal oxide layers in order to establish the effects of surface composition on the activity and selectivity of such catalysts.

Techniques such as Raman spectroscopy, X-ray photoelectron spectroscopy (XPS), X-ray absorption spectroscopy (XAS), and secondary-ion mass spectroscopy (SIMS) cannot give exact information about surface, because these methods probe regions 1-2 $\mathrm{nm}$ in depth. In contrast, a suitable probe molecule can adsorb selectively on surfaces and be detected by its characteristic vibration bands. For the $\mathrm{VO}_{x} / \mathrm{CrO}_{x} / \mathrm{Al}_{2} \mathrm{O}_{3}$ system, an appropriate probe should not only distinguish $\mathrm{V}, \mathrm{Cr}$, and $\mathrm{Al}$ sites but also be sensitive to the vanadium oxidation state $\left(\mathrm{V}^{5+}\right.$,

* Corresponding authors. E-mail: bell@cchem.berkeley.edu (A.T.B.); iglesia@cchem.berkeley.edu (E.I.).

10.1021/jp0582538 CCC: $\$ 33.50$
$\left.\mathrm{V}^{4+}, \mathrm{V}^{3+}\right)$ and that of $\mathrm{Cr}\left(\mathrm{Cr}^{6+}, \mathrm{Cr}^{3+}\right)$. The previous literature suggests that $\mathrm{NO}$ satisfies such requirements and may be useful in the $\mathrm{VCrAl}$ system. Therefore, we chose the infrared spectra of adsorbed NO as a probe of surface-exposed $\mathrm{V}$ and $\mathrm{Cr}$ sites on binary dispersed $\mathrm{VCrAl}$ catalysts. $\mathrm{NO}$ is able to differentiate the surface $\mathrm{V}^{5+}, \mathrm{Cr}^{6+}$, and $\mathrm{Cr}^{3+}$ sites. By comparing $\mathrm{NO}$ adsorbed on $\mathrm{VAl}$ and $\mathrm{CrAl}$ with that on an equivalent monolayer of $\mathrm{VO}_{x}$ and $\mathrm{CrO}_{x}$, the amounts of surface exposed $\mathrm{V}$ and $\mathrm{Cr}$ sites on $\mathrm{VCrAl}$ were measured. These observations are then related to the observed activity and selectivity of $\mathrm{VCrAl}$ catalysts for propane $\mathrm{ODH}$.

\section{Experimental Section}

2.1. Synthesis of Binary Dispersed $\mathrm{VO}_{x} / \mathrm{CrO}_{x} / \mathrm{Al}_{2} \mathrm{O}_{3}$ and $\mathrm{CrO}_{x} / \mathbf{V O}_{x} / \mathrm{Al}_{2} \mathrm{O}_{3} \cdot \mathrm{CrO}_{x} / \mathrm{Al}_{2} \mathrm{O}_{3}(\mathrm{CrAl})$ was prepared by incipientwetness impregnation of fumed $\mathrm{Al}_{2} \mathrm{O}_{3}$ (Degussa AG; surface area $125 \mathrm{~m}^{2} \mathrm{~g}^{-1}$ ) with an aqueous solution of chromium(III) nitrate nonahydrate (Aldrich, 98\%). Samples were dried at 383 $\mathrm{K}$ in ambient air overnight and then treated in flowing dry air (Airgas, zero grade, $3.33 \mathrm{~cm}^{3} \mathrm{~s}^{-1}$ ) by raising its temperature from 298 to $773 \mathrm{~K}$ at $0.167 \mathrm{~K} \mathrm{~s}^{-1}$ and holding at $773 \mathrm{~K}$ for 2 h. $\mathrm{VO}_{x} / \mathrm{Al}_{2} \mathrm{O}_{3}(\mathrm{VAl})$ samples were prepared by incipient-wetness impregnation of $\mathrm{Al}_{2} \mathrm{O}_{3}$ with a 2-propanol (Aldrich, 99.99\%) solution of vanadyl isopropoxide (Aldrich, 98\%). The impregnated alumina was kept in a $\mathrm{N}_{2}$ flow within a glovebox overnight and then was transferred into a quartz reactor sealed with stopcocks. Samples were treated at $393 \mathrm{~K}$ in flowing $\mathrm{N}_{2}$ (Airgas, $99.999 \%, 1.67 \mathrm{~cm}^{3} \mathrm{~s}^{-1}$ ) for $1 \mathrm{~h}$ and at $573 \mathrm{~K}$ for $1 \mathrm{~h}$; then, air (Airgas, zero grade, $1.67 \mathrm{~cm}^{3} \mathrm{~s}^{-1}$ ) was introduced, and samples held at $573 \mathrm{~K}$ for $1 \mathrm{~h}$ and at $773 \mathrm{~K}$ for $2 \mathrm{~h}$. Binary dispersed $\mathrm{VO}_{x} / \mathrm{CrO}_{x} / \mathrm{Al}_{2} \mathrm{O}_{3}(\mathrm{VCrAl})$ catalysts were prepared by incipientwetness impregnation of $\mathrm{CrAl}$ with a 2-propanol solution of vanadyl isopropoxide and were subsequently treated in the same manner as VAl. A $12 \% \mathrm{Cr}_{2} \mathrm{O}_{3} / 10 \% \mathrm{~V}_{2} \mathrm{O}_{5} / \mathrm{Al}_{2} \mathrm{O}_{3}$ (12Cr10VAl) sample was prepared by incipient-wetness impregnation of $10 \%$ 
TABLE 1: BET Surface Areas and $\mathrm{VO}_{x}$ Surface Densities of 12CrAl, $x$ V12CrAl, and $x$ VAl Catalysts

\begin{tabular}{|c|c|c|c|c|c|}
\hline catalyst & denotation & wt $\% \mathrm{~V}_{2} \mathrm{O}_{5}$ & $\begin{array}{l}\text { surface area } \\
\left(\mathrm{m}^{2} \mathrm{~g}^{\left.-\mathrm{cat}^{-1}\right)}\right.\end{array}$ & $\begin{array}{c}\text { surface area } \\
\left(\mathrm{m}^{2} \mathrm{~g}-\mathrm{Al}_{2} \mathrm{O}_{3}^{-1}\right)\end{array}$ & $\begin{array}{c}\mathrm{VO}_{x} \text { surface density } \\
\left(\mathrm{V} \mathrm{nm}^{-2}\right)\end{array}$ \\
\hline $12 \% \mathrm{Cr}_{2} \mathrm{O}_{3} / \mathrm{Al}_{2} \mathrm{O}_{3}$ & $12 \mathrm{CrAl}$ & & 120.0 & 136.4 & $7.9\left(\mathrm{Cr} \mathrm{nm}^{-2}\right)$ \\
\hline $3 \% \mathrm{~V}_{2} \mathrm{O}_{5} / 12 \% \mathrm{Cr}_{2} \mathrm{O}_{3} / \mathrm{Al}_{2} \mathrm{O}_{3}$ & $3 \mathrm{~V} 12 \mathrm{CrAl}$ & $3.0^{a}$ & 94.8 & 111.1 & 2.1 \\
\hline $7 \% \mathrm{~V}_{2} \mathrm{O}_{5} / 12 \% \mathrm{Cr}_{2} \mathrm{O}_{3} / \mathrm{Al}_{2} \mathrm{O}_{3}$ & $7 \mathrm{~V} 12 \mathrm{CrAl}$ & $6.4^{a}$ & 98.6 & 119.7 & 4.3 \\
\hline $10 \% \mathrm{~V}_{2} \mathrm{O}_{5} / 12 \% \mathrm{Cr}_{2} \mathrm{O}_{3} / \mathrm{Al}_{2} \mathrm{O}_{3}$ & $10 \mathrm{~V} 12 \mathrm{CrAl}$ & $8.9^{a}$ & 93.0 & 116.0 & 6.3 \\
\hline $3 \% \mathrm{~V}_{2} \mathrm{O}_{5} / \mathrm{Al}_{2} \mathrm{O}_{3}$ & $3 \mathrm{VAl}$ & $3.1^{a}$ & 108.1 & 111.6 & 1.9 \\
\hline $7 \% \mathrm{~V}_{2} \mathrm{O}_{5} / \mathrm{Al}_{2} \mathrm{O}_{3}$ & 7VAl & $7.3^{a}$ & 119.3 & 128.7 & 4.1 \\
\hline $10 \% \mathrm{~V}_{2} \mathrm{O}_{5} / \mathrm{Al}_{2} \mathrm{O}_{3}$ & 10VAl & $8.3^{a}$ & 103.3 & 112.6 & 5.3 \\
\hline $12 \% \mathrm{~V}_{2} \mathrm{O}_{5} / \mathrm{Al}_{2} \mathrm{O}_{3}$ & $12 \mathrm{VAl}$ & $10.5^{a}$ & 106.0 & 118.4 & 6.5 \\
\hline
\end{tabular}

${ }^{a}$ Obtained by inductively coupled plasma (ICP) analysis.

$\mathrm{V}_{2} \mathrm{O}_{5} / \mathrm{Al}_{2} \mathrm{O}_{3}$ with an aqueous chromium(III) nitrate solution, followed by drying at $383 \mathrm{~K}$ in ambient air and treating in flowing dry air at $773 \mathrm{~K}$ for $2 \mathrm{~h}$.

Crystalline bulk $\mathrm{CrVO}_{4}$ was prepared using the method proposed by Touboul and co-workers. ${ }^{28,29}$ Nitric acid (3N, EM Science, GR) was added to an aqueous solution of $\mathrm{Cr}\left(\mathrm{NO}_{3}\right)_{3}$ and $\mathrm{NH}_{4} \mathrm{VO}_{3}$ to give a $\mathrm{pH}$ of 1 and then was refluxed at $333 \mathrm{~K}$ for $6 \mathrm{~h}$. The precipitate was filtered and washed with $300 \mathrm{~mL}$ of deionized water, dried at $393 \mathrm{~K}$ overnight in ambient air, and then treated in flowing dry air (Airgas, zero grade, 1.67 $\mathrm{cm}^{3} \mathrm{~s}^{-1}$ ) at $1073 \mathrm{~K}$ for $6 \mathrm{~h}$. The X-ray diffraction (XRD) pattern of the as-synthesized sample was measured with a Siemens $\mathrm{D} 5000$ unit at ambient temperature using $\mathrm{CuK} \alpha$ radiation, an X-ray tube operating at $45 \mathrm{kV}$ and $35 \mathrm{~mA}$, and a scan rate of $1.2^{\circ} \mathrm{min}^{-1}$. Crystalline $\mathrm{CrVO}_{4}-\mathrm{I}$ was identified by comparison with literature XRD patterns. ${ }^{39}$

2.2. Catalyst Characterization. BET surface areas were measured by adsorbing $\mathrm{N}_{2}$ at its normal boiling point using a Quantasorb 6 surface analyzer (Quantachrome Corp.). Samples were treated in a dynamic vacuum $(0.1 \mathrm{~Pa})$ at $393 \mathrm{~K}$ for more than $3 \mathrm{~h}$ before BET measurements. The surface areas for all samples are listed in Table 1.

Raman spectra were measured in a Hololab Series 5000 spectrometer (Kaiser Optical) equipped with a frequencydoubled 75-mW Nd:YAG laser (532 nm). Samples were pressed into self-supported wafers (0.9-cm diameter, $\left.\sim 50 \mathrm{mg} \mathrm{cm}^{-2}\right)$ at $200 \mathrm{MPa}$ and then placed onto a rotating holder held within a quartz cell. Spectra were measured at ambient temperature before and after the treating of the samples in flowing dry air (Airgas, zero grade, $0.83 \mathrm{~cm}^{3} \mathrm{~s}^{-1}$ ) by heating to $673 \mathrm{~K}$ at 0.167 $\mathrm{K} \mathrm{s}^{-1}$ and holding at $673 \mathrm{~K}$ for $1 \mathrm{~h}$.

$\mathrm{V}$ and $\mathrm{Cr}$ K-edge X-ray absorption spectra (XAS) were recorded in transmission mode using a Si(111) crystal monochromator at the Stanford Synchrotron Radiation Laboratory using beamline 2-3 and an in situ flow cell. All samples were pressed into $10-\mathrm{mm}$ diameter wafers containing $\sim 15 \mathrm{mg} \mathrm{cm}^{-2}$ of catalyst. Energy resolutions for the spectra were $5 \mathrm{eV}$ in the preedge region, $0.25 \mathrm{eV}$ in the edge region, and $2.5 \mathrm{eV}$ in the fine structure region. X-ray absorption data were analyzed using IFEFFIT Athena software (version 1.0068). The energy was calibrated using the first inflection point in the spectra for $\mathrm{V}$ or $\mathrm{Cr}$ foils collected concurrently with each sample spectrum (5465 $\mathrm{eV}$ for $\mathrm{V}$ and $5989 \mathrm{eV}$ for $\mathrm{Cr}$ ).

Temperature-programmed reduction (TPR) studies were conducted in a flow QS-10 unit (Quantachrome Corp.). $\mathrm{H}_{2}$ concentrations were measured using a thermal conductivity detector calibrated by reducing bulk $\mathrm{CuO}$ powder (Aldrich, $99.995 \%)$. The amount of sample (15-100 mg) was chosen to maintain the same number of oxygen atoms in all experiments. Samples were treated at $1173 \mathrm{~K}$ in $20 \% \mathrm{H}_{2}-\mathrm{Ar}$ (Praxair, $99.999 \%$ ) at $0.167 \mathrm{~K} \mathrm{~s}^{-1}$ and were held at $1173 \mathrm{~K}$ for $1 \mathrm{~h} . \mathrm{H}_{2} \mathrm{O}$ formed during reduction was removed before thermal conductivity detection using a $13 \mathrm{X}$ sieve trap held at ambient temperature.

Oxygen desorption rates during thermal treatment $\left(\mathrm{O}_{2}-\mathrm{TPD}\right)$ were measured in a flow system using a mass spectrometer ( $\mathrm{LH}$ INFICON Transpector) to detect $\mathrm{O}_{2}$. Each sample (100 mg) was placed within a U-shaped quartz cell and treated in flowing $20 \%$ $\mathrm{O}_{2}-\mathrm{Ar}$ (Praxair, $99.999 \%, 0.83 \mathrm{~cm}^{3} \mathrm{~s}^{-1}$ ) at $773 \mathrm{~K}$ for $1 \mathrm{~h}$. The samples were then cooled to ambient temperature in this $\mathrm{O}_{2}-$ Ar mixture and flushed with He (Praxair, 99.999\%, $0.83 \mathrm{~cm}^{3}$ $\mathrm{s}^{-1}$ ) until the 32 amu signal reached constant background levels. Then, the temperature was increased from 298 to $1173 \mathrm{~K}$ at $0.167 \mathrm{~K} \mathrm{~s}^{-1}$ and was held at $1173 \mathrm{~K}$ for $0.5-1 \mathrm{~h}$.

Infrared spectra were measured in a glass vacuum system using self-supporting wafers (ca. $10 \mathrm{mg} \mathrm{cm}^{-2}$ ) and a quartz cell. $\mathrm{NaCl}$ windows were attached to the cell using silicon glue (Dow Corning 838), which allowed evacuation to $\sim 1 \times 10^{-3} \mathrm{~Pa}$. A heater surrounded the stainless steel tube in the central portion of the cell, which allowed the cell to be heated to $873 \mathrm{~K}$ or cooled to $\sim 150 \mathrm{~K}$ by allowing liquid nitrogen to flow through the stainless steel tube. While heating or cooling the cell, water flowed through a copper tube surrounding the regions near the $\mathrm{NaCl}$ windows to minimize thermal shock to the windows and condensation of water vapor. A sample wafer held in a quartz sample holder was placed in the center of the cell. The sample temperature was measured by a K-type thermocouple positioned close to the center of the wafer. Samples were treated in flowing dry air (Praxair, zero grade, $1.67 \mathrm{~cm}^{3} \mathrm{~s}^{-1}$ ) at $773 \mathrm{~K}$ for $1 \mathrm{~h}$, evacuating them at $773 \mathrm{~K}$ for $1 \mathrm{~h}$ and treating them with pure $\mathrm{O}_{2}\left(1.3 \times 10^{4} \mathrm{~Pa}\right)$ at $773 \mathrm{~K}$ for $1 \mathrm{~h}$ to remove adsorbed impurities. The samples were cooled to ambient temperature in $\mathrm{O}_{2}$ and then evacuated. The samples treated in this manner are denoted as oxidized samples. After sample pretreatment, the samples were cooled to $153 \mathrm{~K}$ in a vacuum before introduction of NO as a probe molecule. NO (Airgas, 99.98\%) was purified by vacuum distillation and several freeze-pump-thaw cycles before use. NO was dosed into the quartz cell until its pressure reached $120 \mathrm{~Pa}$. Infrared spectra were recorded at a resolution of $4 \mathrm{~cm}^{-1}$ on a Nicolet NEXUS 670 FT-IR spectrometer equipped with an MCT detector with 64 scans in the 4250$400 \mathrm{~cm}^{-1}$ region. Difference spectra were obtained by subtracting spectra before NO adsorption at each temperature.

2.3. Catalytic Rates and Selectivity Measurements. Detailed procedures for measurement and analysis of reaction rates and selectivities have been reported previously. ${ }^{27}$ Oxidative dehydrogenation rates and selectivities were measured at 583$673 \mathrm{~K}$ using a vertical quartz microreactor. Catalyst samples (20-40 mg; 250-500 $\mu \mathrm{m}$ aggregates) were diluted with equal amounts of acid-washed quartz powder $(250-500 \mu \mathrm{m})$. The reactant mixture consisted of $\mathrm{C}_{3} \mathrm{H}_{8}(13.5 \mathrm{kPa}$, Airgas, $99.9 \%)$ and $\mathrm{O}_{2}(1.7 \mathrm{kPa}$, Airgas, $99.999 \%)$ with $\mathrm{He}$ as the balance (Airgas, 99.999\%). Reactant and product concentrations were 


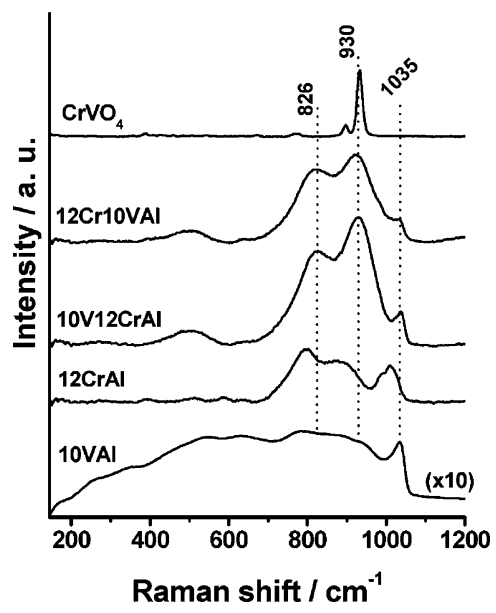

Figure 1. Raman spectra of $10 \mathrm{VAl}, 12 \mathrm{CrAl}, 10 \mathrm{~V} 12 \mathrm{CrAl}$, and $12 \mathrm{Cr} 10 \mathrm{VAl}$ treated in flowing dry air at $673 \mathrm{~K}$ for $1 \mathrm{~h}$. The spectrum of $\mathrm{CrVO}_{4}$ is also given as a reference.

measured by gas chromatography (Hewlett-Packard 6890) using a Carboxen 1004 packed column and an HP-PLOT Q capillary column with thermal conductivity and flame ionization detectors, respectively.

\section{Results and Discussion}

3.1. Structure of VAl, CrAl, VCrAl, and CrVAl. Figure 1 shows Raman spectra for $10 \mathrm{VAl}, 12 \mathrm{CrAl}, 10 \mathrm{~V} 12 \mathrm{CrAl}$, and $12 \mathrm{Cr} 10 \mathrm{VAl}$ and the spectrum for crystalline $\mathrm{CrVO}_{4}$. The spectrum of 10VAl shows bands at 1035, 900, 785, 636, 547, 350 , and $266 \mathrm{~cm}^{-1}$, attributed to two types of $\mathrm{V}$-oxo species. The band at $1035 \mathrm{~cm}^{-1}$ is assigned to $\mathrm{V}=\mathrm{O}$ stretches in monovanadates and polyvanadates, while the pairs of broad bands at 900 and $785 \mathrm{~cm}^{-1}, 636$ and $547 \mathrm{~cm}^{-1}$, and 350 and $266 \mathrm{~cm}^{-1}$ are attributed to antisymmetric stretches, symmetric stretches, and deformation modes of $\mathrm{V}-\mathrm{O}-\mathrm{V}$ bonds, respectively, in polyvanadate domains of varying size. ${ }^{27,30}$ The spectrum of $12 \mathrm{CrAl}$, with an equivalent $\mathrm{CrO}_{x}$ monolayer (7.9 $\left.\mathrm{Cr} \mathrm{nm}^{-2}\right),{ }^{31}$ shows three intense bands at 1009, 879, and 799 $\mathrm{cm}^{-1}$. The $1009-\mathrm{cm}^{-1}$ band is attributed to $\mathrm{Cr}=\mathrm{O}$ stretches in isolated monochromates, while the 879 and $799-\mathrm{cm}^{-1}$ bands are assigned to $\mathrm{Cr}-\mathrm{O}-\mathrm{Cr}$ stretches in dichromates and trichromates. ${ }^{31-34}$ The weak band at $986 \mathrm{~cm}^{-1}$ is assigned to crystalline $\mathrm{CrO}_{3}$ (bands at 975 and $495 \mathrm{~cm}^{-1}$ ), but no bands for crystalline $\mathrm{Cr}_{2} \mathrm{O}_{3}$ (i.e., $550 \mathrm{~cm}^{-1}$ ) were detected in any of the samples. ${ }^{30}$ Upon deposition of $\mathrm{VO}_{x}$ on $12 \mathrm{CrAl}$, the bands at $1009,986,879$, and $799 \mathrm{~cm}^{-1}$ weakened, and when the $\mathrm{VO}_{x}$ deposited reached an equivalent monolayer (10V12CrAl, Figure $1)$, they were replaced by a band at $1037 \mathrm{~cm}^{-1}$, corresponding to $\mathrm{V}=\mathrm{O}$ stretches; two broad bands at 930 and $820 \mathrm{~cm}^{-1}$ were also observed, and these are assigned below. When an equivalent monolayer of $\mathrm{CrO}_{x}$ was deposited on $10 \mathrm{VAl}$ (12 Cr10VAl), the spectrum for this sample resembled that for $10 \mathrm{~V} 12 \mathrm{CrAl}$.

The band at $930 \mathrm{~cm}^{-1}$ resembles that seen in the spectrum of crystalline $\mathrm{CrVO}_{4}$ prepared from $\mathrm{Cr}\left(\mathrm{NO}_{3}\right)_{3}$ and $\mathrm{NH}_{4} \mathrm{VO}_{3}$ (Figure 1), and hence, it is assigned to $\mathrm{V}-\mathrm{O}-\mathrm{Cr}$ stretches. ${ }^{35,36}$ In the breadth of this band for $10 \mathrm{~V} 12 \mathrm{CrAl}$ and $12 \mathrm{Cr} 10 \mathrm{VAl}$ and in the absence of $\mathrm{CrVO}_{4}$, diffraction lines for these samples suggest that the $\mathrm{CrVO}_{4}$ domains are disordered and highly dispersed. ${ }^{27,37-39}$ The $820 \mathrm{~cm}^{-1}$ band may reflect the presence of polychromates, polyvanadates, or mixed $\mathrm{V}-\mathrm{O}-\mathrm{Cr}$ oligomers, but its specific origin remains unclear.

Figure 2 shows X-ray absorption near-edge spectroscopy (XANES) spectra for 10VAl, 12CrAl, 10V12CrAl, and

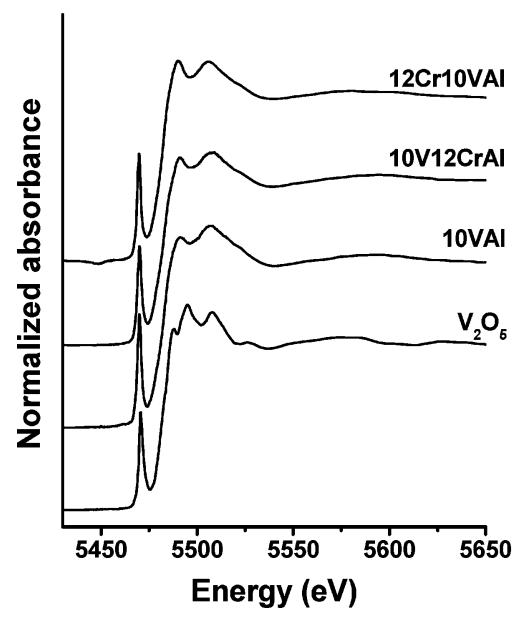

(a) V K-edge

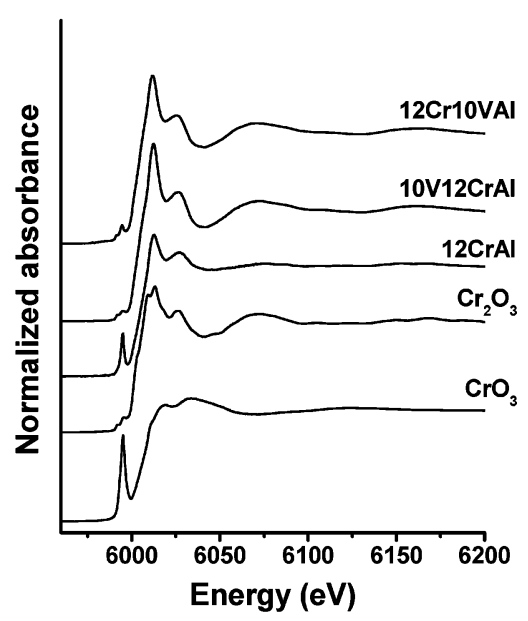

(b) Cr K-edge

Figure 2. Near-edge $\mathrm{X}$-ray absorption spectra of (a) $\mathrm{V}$ K-edge of $\mathrm{V}_{2} \mathrm{O}_{5}$, $10 \mathrm{VAl}, 10 \mathrm{~V} 12 \mathrm{CrAl}$, and $12 \mathrm{Cr} 10 \mathrm{VAl}$; and (b) $\mathrm{Cr} \mathrm{K}$-edge of $\mathrm{CrO}_{3}$, $\mathrm{Cr}_{2} \mathrm{O}_{3}, 12 \mathrm{CrAl}, 10 \mathrm{~V} 12 \mathrm{CrAl}$, and 12Cr10VAl.

$12 \mathrm{Cr} 10 \mathrm{VAl}$ after treatment at $773 \mathrm{~K}$ for $2 \mathrm{~h}$ in flowing dry air and for three crystalline compounds $\mathrm{V}_{2} \mathrm{O}_{5}, \mathrm{CrO}_{3}, \mathrm{Cr}_{2} \mathrm{O}_{3}$. The spectrum for $\mathrm{V}_{2} \mathrm{O}_{5}$ (Figure $2 \mathrm{a}$ ) has two features $(\alpha$ and $\beta$ ) above the edge, attributable to $\mathrm{V}_{2} \mathrm{O}_{5}$ crystallites. ${ }^{40,41}$ Near-edge spectra for $10 \mathrm{VAl}, 10 \mathrm{~V} 12 \mathrm{CrAl}$, and $12 \mathrm{Cr} 10 \mathrm{VAl}$ are similar; they differ clearly from the spectrum of $\mathrm{V}_{2} \mathrm{O}_{5}$, suggesting the absence of large $\mathrm{V}_{2} \mathrm{O}_{5}$ crystallites. The preedge feature in 10VAl is slightly more intense than in $10 \mathrm{~V} 12 \mathrm{CrAl}$ and $12 \mathrm{Cr} 10 \mathrm{VAl}$, indicating that $\mathrm{V}$ centers in $10 \mathrm{VAl}$ reside in a less centrosymmetric environment than in the other two samples and that the coordination environment of $\mathrm{VO}_{x}$ species in the three samples is influenced by the presence of $\mathrm{CrO}_{x}$.

The $\mathrm{Cr}$ near-edge spectrum for $\mathrm{CrO}_{3}$ shows a sharp preedge feature at $\sim 5992 \mathrm{eV}$ resulting from dipole-forbidden $1 \mathrm{~s}$ to $3 \mathrm{~d}$ transitions that become allowed as a result of orbital hybridization in non-centrosymmetric structures. ${ }^{42,43}$ This preedge feature is very weak in the spectrum of $\mathrm{Cr}_{2} \mathrm{O}_{3}$ (Figure 2b), as it is also for reduced $\mathrm{CrO}_{x}{ }^{43} 12 \mathrm{CrAl}$ gives a weaker preedge feature than $\mathrm{CrO}_{3}$, while the preedge and near-edge spectral regions in $10 \mathrm{~V} 12 \mathrm{CrAl}$ and $12 \mathrm{Cr} 10 \mathrm{VAl}$ resemble those in $\mathrm{Cr}_{2} \mathrm{O}_{3}$, suggesting the predominant presence of $\mathrm{Cr}^{3+}$ in these three samples. The amounts of $\mathrm{Cr}^{3+}$ in $12 \mathrm{CrAl}, 10 \mathrm{~V} 12 \mathrm{CrAl}$, and $12 \mathrm{Cr} 10 \mathrm{VAl}$ were estimated to be $\sim 50 \%,>90 \%$, and $\sim 85 \%$, respectively, using linear superimposition analysis of the preedge region with $\mathrm{CrO}_{3}$ and $\mathrm{Cr}_{2} \mathrm{O}_{3}$ as standards; these $\mathrm{Cr}^{3+}$ contents are consistent with reduction data presented below. 

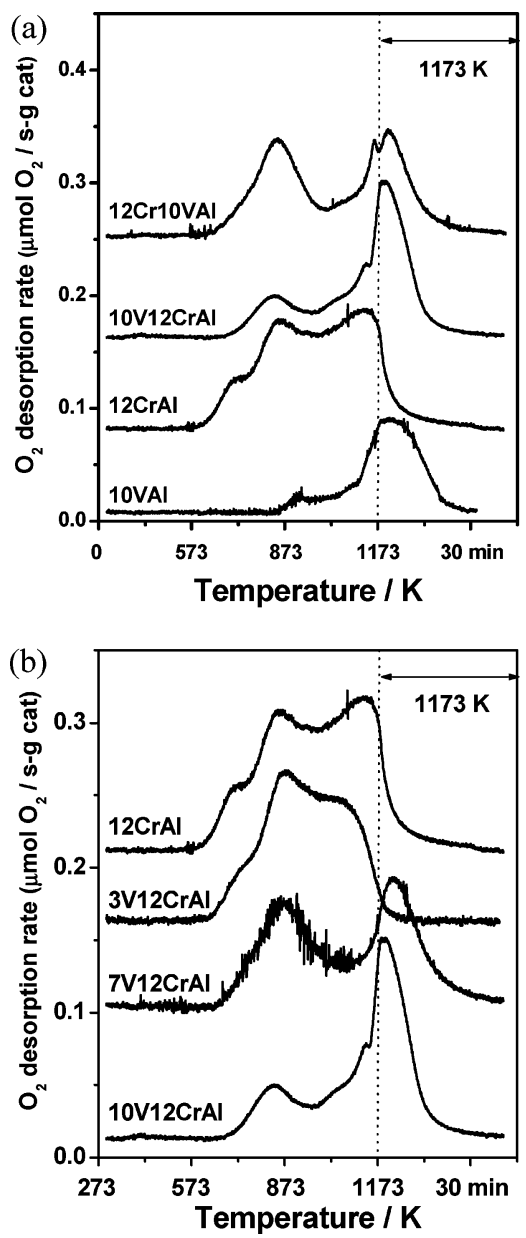

Figure 3. (a) $\mathrm{O}_{2}$-TPD profiles of $10 \mathrm{VAl}, 12 \mathrm{CrAl}, 10 \mathrm{~V} 12 \mathrm{CrAl}$, and $12 \mathrm{Cr} 10 \mathrm{VAl}$ treated in flowing $20 \% \mathrm{O}_{2}-\mathrm{Ar}$ at $773 \mathrm{~K}$ for $1 \mathrm{~h}$. (b) $\mathrm{O}_{2-}$ TPD profiles of $x \mathrm{~V} 12 \mathrm{CrAl}(x=3-10)$ with various $\mathrm{VO}_{x}$ surface densities.

Figure 3 shows the dynamics of $\mathrm{O}_{2}$ evolution during thermal treatment in $\mathrm{He}$ for $10 \mathrm{VAl}, 12 \mathrm{CrAl}, 10 \mathrm{~V} 12 \mathrm{CrAl}$, and $12 \mathrm{Cr} 10 \mathrm{VAl}$ samples pretreated in $20 \% \mathrm{O}_{2}-\mathrm{Ar}$ at $773 \mathrm{~K}$ for $1 \mathrm{~h}$. On $10 \mathrm{VAl}$, $\mathrm{O}_{2}$ desorbs predominantly above $1173 \mathrm{~K}$, but a small oxygen desorption peak is observed at $923 \mathrm{~K} . \mathrm{O}_{2}$ desorbs from $12 \mathrm{CrAl}$ in three peaks at 718,854 , and $1131 \mathrm{~K}$. Raman spectroscopy (Figure 1) suggests that traces of $\mathrm{CrO}_{3}$ are present in $12 \mathrm{CrAl}$; thus, we suggest that the shoulder at $718 \mathrm{~K}$ arises from $\mathrm{O}_{2}$ desorption from $\mathrm{CrO}_{3}$ species in $12 \mathrm{CrAl}$, while desorption features at 854 and $1131 \mathrm{~K}$ reflect desorption from polychromate domains of varying size. ${ }^{44}$

$\mathrm{O}_{2}$ desorption peaks for $\mathrm{CrO}_{x}(718,854$, and $1131 \mathrm{~K})$ become smaller when an equivalent $\mathrm{VO}_{x}$ monolayer is deposited onto $12 \mathrm{CrAl}$, and a peak appears at $>1173 \mathrm{~K}$, as in the case of $\mathrm{O}_{2}$ desorption from $\mathrm{VO}_{x}$ domains in 10VAl. The low-temperature desorption peaks, characteristic of $\mathrm{CrO}_{x}$ species, were also smaller for $12 \mathrm{Cr} 10 \mathrm{VAl}$ than for $12 \mathrm{CrAl}$ but larger than for $10 \mathrm{~V} 12 \mathrm{CrAl}$ samples, again suggesting an effect of deposition sequence on structure and oxygen reactivity. These effects of $\mathrm{V}$ on the desorption of $\mathrm{O}_{2}$ from the $\mathrm{CrO}_{x}$ component reflects the predominant presence of $\mathrm{Cr}^{3+}$ in these samples as a result of the formation of $\mathrm{CrVO}_{4}$.

Figure $3 \mathrm{~b}$ shows the effects of $\mathrm{VO}_{x}$ surface density on the dynamics of $\mathrm{O}_{2}$ evolution from $\mathrm{CrO}_{x}$ species for $12 \mathrm{CrAl}$ and $x \mathrm{~V} 12 \mathrm{CrAl}(x=3-10)$ samples with a wide range of $\mathrm{VO}_{x}$ surface densities $\left(1.9-6.5 \mathrm{~V} \mathrm{~nm}{ }^{-2}\right)$. The intensity of $\mathrm{O}_{2}$ desorption peaks from $\mathrm{CrO}_{x}$ decreased monotonically with increasing $\mathrm{VO}_{x}$ surface density. These data indicate that the

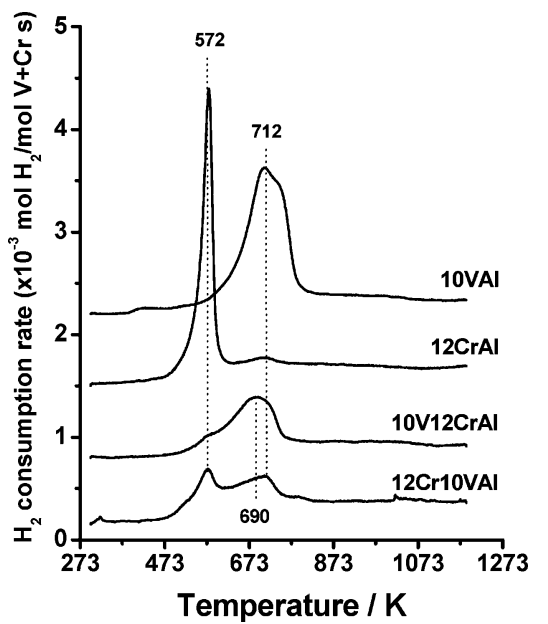

Figure 4. TPR profiles of $10 \mathrm{VAl}, 12 \mathrm{CrAl}, 10 \mathrm{~V} 12 \mathrm{CrAl}$, and $12 \mathrm{Cr} 10 \mathrm{VAl}$ catalysts.

TABLE 2: $\mathrm{O}_{2}$ Desorbed from $\mathrm{CrO}_{x}\left(\mathrm{~mol}^{-\mathrm{O}_{2}} \mathrm{~mol}^{\left.-\mathrm{Cr}^{-1}\right)}\right.$ on Each $x$ V12CrAl Sample

\begin{tabular}{ll}
\hline \multicolumn{1}{c}{ sample } & $\mathrm{O}_{2} / \mathrm{Cr}$ \\
\hline $12 \mathrm{CrAl}$ & 0.11 \\
$3 \mathrm{~V} 12 \mathrm{CrAl}$ & 0.092 \\
$7 \mathrm{~V} 12 \mathrm{CrAl}$ & 0.069 \\
$10 \mathrm{~V} 12 \mathrm{CrAl}$ & 0.032
\end{tabular}

amount of $\mathrm{O}_{2}$ desorbed from $\mathrm{CrO}_{x}\left(\mathrm{O}_{2} / \mathrm{Cr}\right)$ also decreased with increasing $\mathrm{VO}_{x}$ surface density (Table 2). Thus, the fraction of the $\mathrm{Cr}$ atoms with desorbable oxygens, (e.g., $\mathrm{Cr}^{6+}$ ) in $x \mathrm{~V} 12 \mathrm{CrAl}$ decreases with increasing $\mathrm{VO}_{x}$ surface density, because of the concurrent formation of $\mathrm{CrVO}_{4}$.

Figure 4 shows the dynamics of the reduction in $\mathrm{H}_{2}$ for $10 \mathrm{VAl}, 12 \mathrm{CrAl}, 10 \mathrm{~V} 12 \mathrm{CrAl}$, and $12 \mathrm{Cr} 10 \mathrm{VAl}$ as a function of temperature. $\mathrm{H}_{2}$ was consumed in a peak at $712 \mathrm{~K}$ with a shoulder at $745 \mathrm{~K}$ in $10 \mathrm{VAl}$; these features have been attributed to reduction of $\mathrm{V}^{5+}$ to $\mathrm{V}^{3+}$ in polyvanadates, based on the measured ratio of $\mathrm{H}_{2}$ consumed to total amount of $\mathrm{VO}_{x}{ }^{16,26,27}$ The two reduction peaks are consistent with the presence of polyvanadate domains, as also inferred from the Raman spectra (Figure 1). The $12 \mathrm{CrAl}$ sample reduces in a peak at $578 \mathrm{~K}$, assigned to $\mathrm{Cr}^{6+}$ reduction to $\mathrm{Cr}^{3+} .15$ Two other $\mathrm{H}_{2}$ consumption peaks appear at 572 and $690 \mathrm{~K}$ for $10 \mathrm{~V} 12 \mathrm{CrAl}$ and $12 \mathrm{Cr} 10 \mathrm{VAl}$, corresponding to the reduction of $\mathrm{Cr}^{6+}$ to $\mathrm{Cr}^{3+}$ and $\mathrm{V}^{5+}$ to $\mathrm{V}^{3+}$, respectively. ${ }^{12,26,27}$ The reduction peak temperature for $\mathrm{VO}_{x}$ species in a binary dispersed sample is lower than that for VAl, indicating that the presence of $\mathrm{CrO}_{x}$ promotes the reduction of $\mathrm{VO}_{x}$. The reason for this promotional effect of $\mathrm{CrO}_{x}$ is not understood, but it may reflect a change in the electronic properties of $\mathrm{VO}_{x}$ caused by the formation of $\mathrm{CrVO}_{4}$. It should also be noted that the $\mathrm{CrO}_{x}$ reduction peak at $572 \mathrm{~K}$ for $10 \mathrm{~V} 12 \mathrm{CrAl}$ is smaller than that for $12 \mathrm{Cr} 10 \mathrm{VAl}$, indicating that 12Cr10VAl contains a greater concentration of $\mathrm{Cr}^{6+}$ than $10 \mathrm{~V} 12 \mathrm{CrAl}$.

Figure 5a shows reduction rates (per $\mathrm{Cr}$ atom) for $12 \mathrm{CrAl}$ and $x \mathrm{~V} 12 \mathrm{CrAl}(x=3-10)$. The features for $\mathrm{CrO}_{x}$ reduction become less intense as $\mathrm{VO}_{x}$ surface density increases; in $10 \mathrm{~V} 12 \mathrm{CrAl}$, this reduction process appears as a small shoulder next to the $\mathrm{VO}_{x}$ reduction peak, indicating that the fraction of the $\mathrm{Cr}$ present as $\mathrm{Cr}^{6+}$ in $10 \mathrm{~V} 12 \mathrm{CrAl}$ is much smaller than in that $12 \mathrm{CrAl}$. All $\mathrm{V}^{5+}$ ions in this sample were reduced to $\mathrm{V}^{3+} .27$ These data confirm that deposition of $\mathrm{VO}_{x}$ on $12 \mathrm{CrAl}$ forms dispersed $\mathrm{CrVO}_{4}$ during thermal treatment; all $\mathrm{Cr}$ atoms in $\mathrm{CrVO}_{4}$ are trivalent, and $\mathrm{V}^{5+}$ ions are more readily reduced than $\mathrm{VO}_{x}$ structures dispersed on $\mathrm{Al}_{2} \mathrm{O}_{3}$. 

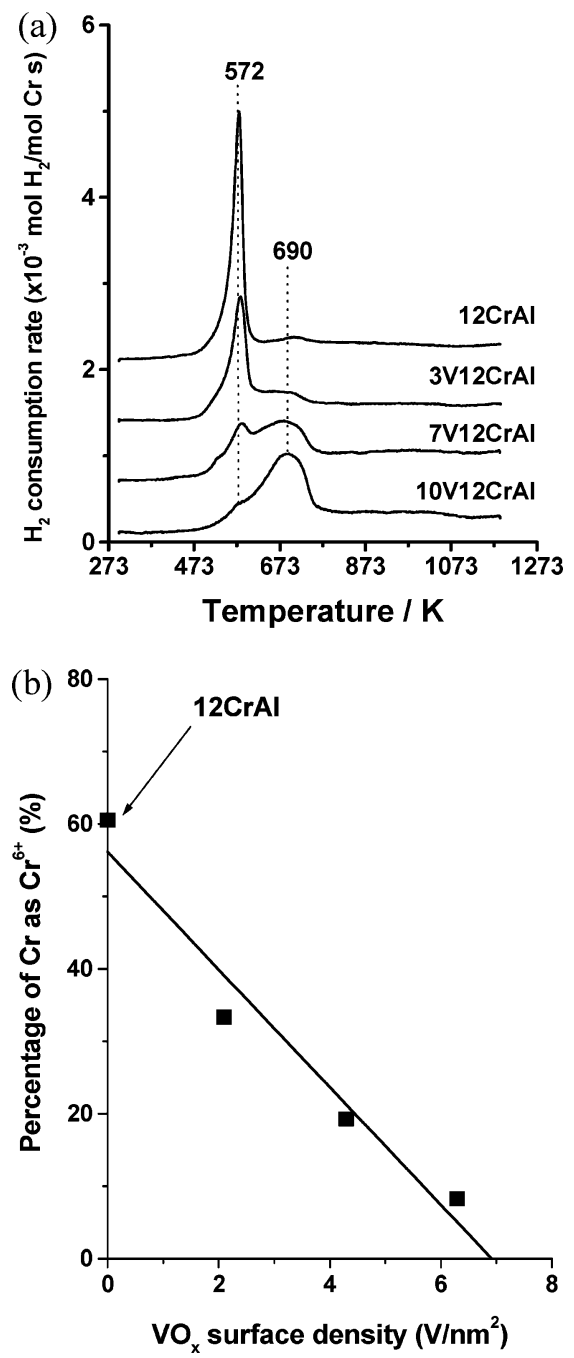

Figure 5. (a) TPR profiles of $12 \mathrm{CrAl}$ and $x \mathrm{~V} 12 \mathrm{CrAl}(x=3-10)$ catalysts. (b) Percentage of $\mathrm{Cr}$ as $\mathrm{Cr}^{6+}$ in $12 \mathrm{CrAl}, x \mathrm{~V} 12 \mathrm{CrAl}$, and $12 \mathrm{Cr} 10 \mathrm{VAl}$ catalysts as calculated from TPR data (dividing real value of consumed $\mathrm{H}_{2}$ by theoretical value). It is assumed that all $\mathrm{Cr}^{6+}$ were reduced to $\mathrm{Cr}^{3+}$.

The reduction profiles in Figure 5a were deconvoluted (Gaussian Function and Origin; version 7.0), and individual components were integrated to estimate the amount of $\mathrm{H}_{2}$ consumed $\left(\mathrm{H}_{2} / \mathrm{Cr}\right)$ within each reduction peak. These $\mathrm{H}_{2} / \mathrm{Cr}$ ratios were divided by the value expected for the reduction of all $\mathrm{Cr}$ atoms from $\mathrm{Cr}^{6+}$ to $\mathrm{Cr}^{3+}$ (Figure 5b), which reflects the fraction of $\mathrm{Cr}$ present as $\mathrm{Cr}^{6+}$. Only $\sim 60 \%$ of the $\mathrm{Cr}$ atoms are present as $\mathrm{Cr}^{6+}$ in $12 \mathrm{CrAl}$ after thermal treatment in air, suggesting that the autoreduction of $\mathrm{CrO}_{x}$ structures occurred during this treatment. The presence of $\mathrm{VO}_{x}$ favors $\mathrm{Cr}^{3+}$ by stabilizing it in $\mathrm{CrVO}_{4}$ structures; only $8 \%$ of the $\mathrm{Cr}$ atoms are in the $\mathrm{Cr}^{6+}$ state in $10 \mathrm{~V} 12 \mathrm{CrAl}$, consistent with $\mathrm{X}$-ray absorption and $\mathrm{O}_{2}$ evolution data.

In summary, Raman and $\mathrm{X}$-ray absorption spectra and $\mathrm{O}_{2}$ evolution and $\mathrm{H}_{2}$ consumption dynamics show that $\mathrm{Cr}^{3+}$ forms in $12 \mathrm{CrAl}$ and $\mathrm{VCrAl}$ samples. In the presence of $\mathrm{CrO}_{x}, \mathrm{VO}_{x}$ species are more readily reduced than in $\mathrm{VO}_{x}$-only structures dispersed on $\mathrm{Al}_{2} \mathrm{O}_{3}$. The deposition sequence of $\mathrm{VO}_{x}$ and $\mathrm{CrO}_{x}$ influenced the structure and oxygen reactivity of binary $\mathrm{VCr}$ oxides dispersed on $\mathrm{Al}_{2} \mathrm{O}_{3}$.

3.2. Surface Composition of VCrAl and CrVAl and Relationship to Catalyst Activity and Selectivity. NO was used to prove the nature and number of $\mathrm{V}$ and $\mathrm{Cr}$ species exposed at surfaces. $\mathrm{NO}$ adsorbs strongly on $\mathrm{V}^{3+}$ or $\mathrm{V}^{4+}$ or
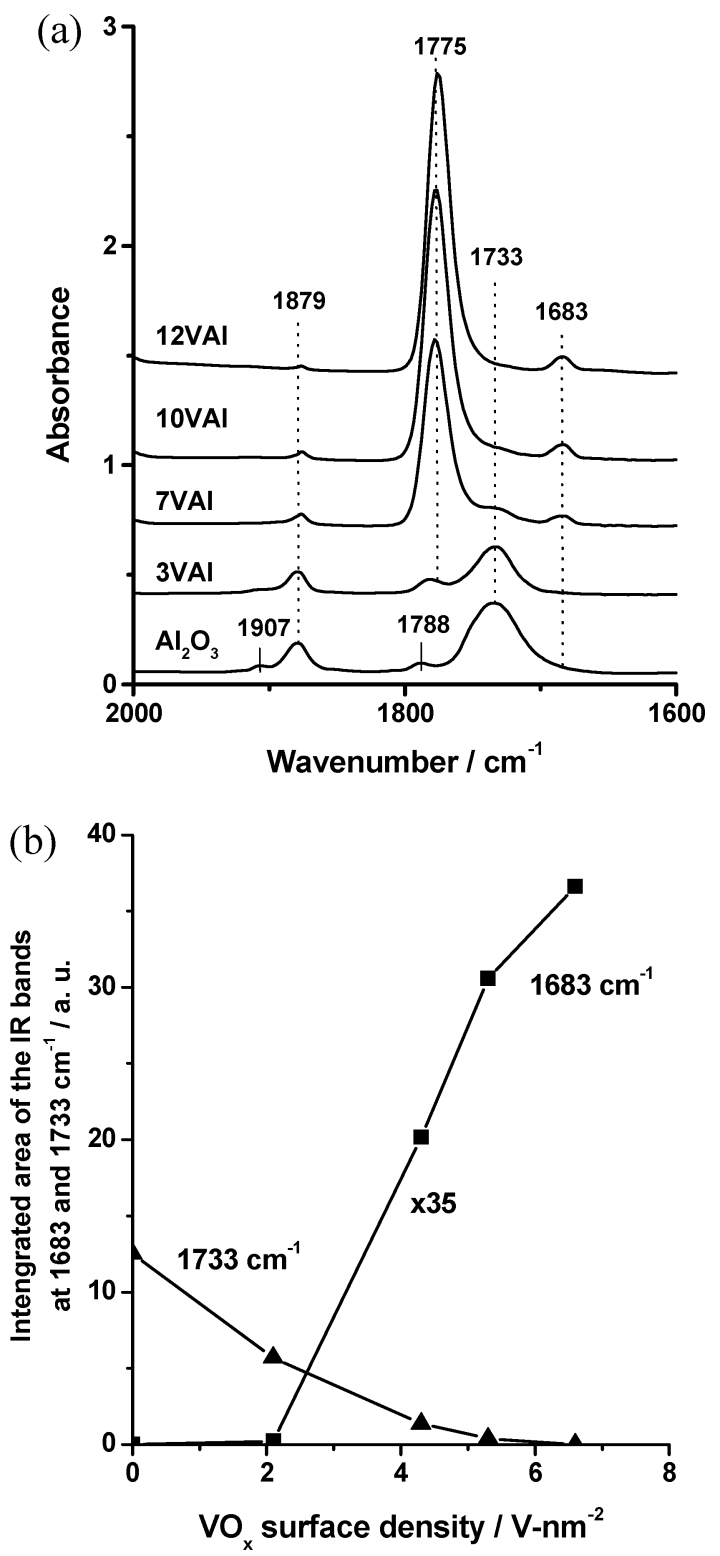

Figure 6. (a) IR spectra of $\mathrm{NO}$ adsorbed on oxidized $x \mathrm{VAl}(x=3-12)$ treated in $\mathrm{O}_{2}$ (100 Torr) at $773 \mathrm{~K}$ for $1 \mathrm{~h}$. (b) Integrated intensities of the IR bands at 1683 and $1733 \mathrm{~cm}^{-1}$ in part a as a function of $\mathrm{VO}_{x}$ surface density.

both but adsorbs much more weakly on $\mathrm{V}^{5+}$ at ambient temperature..$^{45-48}$ Since only $\mathrm{V}^{5+}$ is present in the materials of interest for this study, $\mathrm{NO}$ was adsorbed at $153 \mathrm{~K}$. Figure $6 \mathrm{a}$ shows infrared spectra for $\mathrm{NO}$ adsorbed at $153 \mathrm{~K}$ on $\mathrm{Al}_{2} \mathrm{O}_{3}$ and $x \mathrm{VAl}\left(x=3-12,1.9-6.5 \mathrm{~V} \mathrm{~nm}^{-2}\right)$. Four bands are observed at $1907,1879,1788$, and $1733 \mathrm{~cm}^{-1}$ that can be assigned to cis-ONNO dimers $(\mathrm{O}=\mathrm{N}-\mathrm{N}=\mathrm{O})$ based their positions. ${ }^{49,50}$ The infrared bands for $\mathrm{NO}$ dimers on $\mathrm{Al}_{2} \mathrm{O}_{3}$ are observed on $3 \mathrm{VAl}$ $\left(1.9 \mathrm{~V} \mathrm{~nm}^{-2}\right)$, but their intensities are slightly lower than those on pure $\mathrm{Al}_{2} \mathrm{O}_{3}$. Infrared bands for $\mathrm{NO}$ adsorbed on $\mathrm{V}^{5+}$ appear at 1683 and $1775 \mathrm{~cm}^{-1}$. The bands for $\mathrm{NO}$ dimers on $\mathrm{Al}_{2} \mathrm{O}_{3}$ become weaker as the $\mathrm{VO}_{x}$ surface density increases and cannot be detected above $6.5 \mathrm{~V} \mathrm{~nm}^{-2}$; the two bands at 1775 and 1683 $\mathrm{cm}^{-1}$ become stronger as the $\mathrm{VO}_{x}$ surface density increases. The concurrent increase in the intensity of these two bands lead us to assign them to the same structure, specifically to the formation of antisymmetric NONO dimers $(\mathrm{N}=\mathrm{O} \cdots \mathrm{N}=\mathrm{O})$ adsorbed on $\mathrm{VO}_{x}{ }^{50}$

The integrated area of the band at $1683 \mathrm{~cm}^{-1}$ is shown as a function of the $\mathrm{VO}_{x}$ surface density in Figure 6b. The intensity 

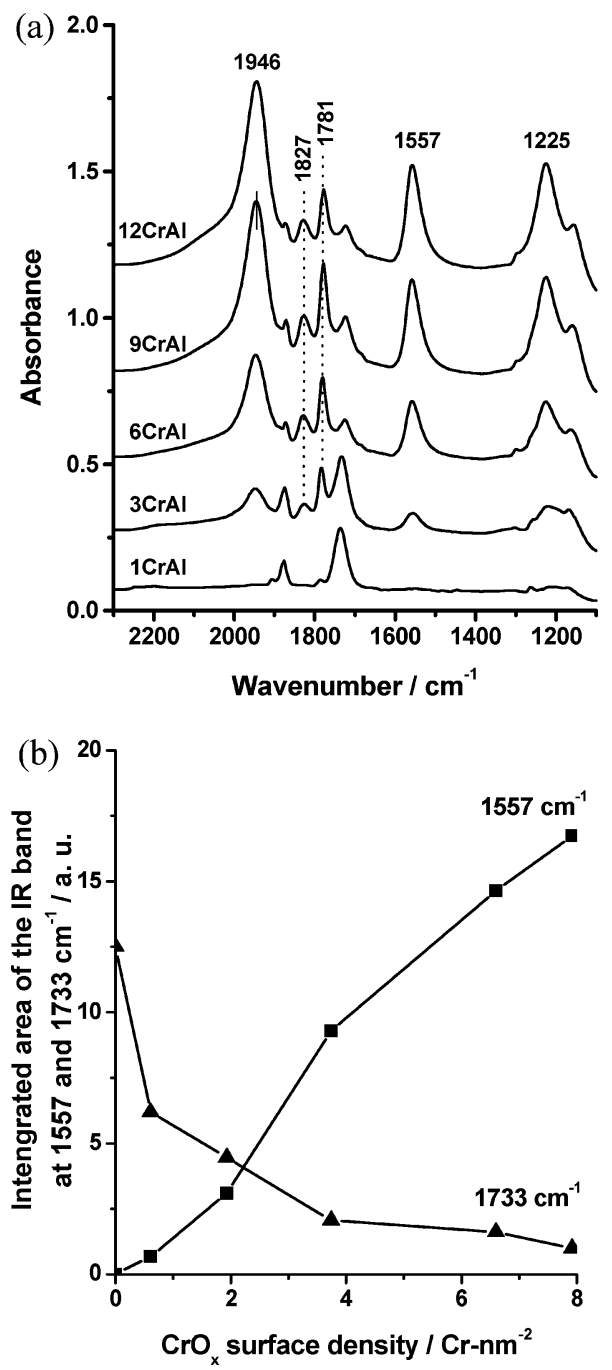

Figure 7. (a) IR spectra of $\mathrm{NO}$ adsorbed on oxidized $x \mathrm{CrAl}(x=1-12)$ treated in $\mathrm{O}_{2}$ (100 Torr) at $773 \mathrm{~K}$ for $1 \mathrm{~h}$. (b) Integrated intensities of the IR bands at 1557 and $1733 \mathrm{~cm}^{-1}$ in part a as a function of $\mathrm{CrO}_{x}$ surface density.

of this feature is nearly zero for $\mathrm{VO}_{x}$ surface densities below 3 $\mathrm{V} \mathrm{nm}{ }^{-2}$ but then increased linearly with increasing $\mathrm{VO}_{x}$ surface density in the range of 3-7 $\mathrm{V} \mathrm{nm}^{-2}$. Raman spectra showed that monovanadates predominate for $\mathrm{VAl}$ samples with $<3 \mathrm{~V}$ $\mathrm{nm}^{-2}$, while polyvanadates increased in concentration as surface densities increased above $3 \mathrm{~V} \mathrm{~nm}^{-2}$. Thus, ONON dimers appear to form only on polyvanadate species. The integrated intensities for the band at $1733 \mathrm{~cm}^{-1}$ are also shown in Figure $6 \mathrm{~b}$. The intensity of this band decreased monotonically with increasing $\mathrm{VO}_{x}$ surface density, as expected from the gradual coverage of $\mathrm{Al}_{2} \mathrm{O}_{3}$ surfaces and the concomitant reactions of $\mathrm{OH}$ groups with V-oxyhydroxide species during deposition and thermal treatment.

Infrared spectra for $\mathrm{NO}$ adsorbed on $\mathrm{CrO}_{x} / \mathrm{Al}_{2} \mathrm{O}_{3}$ differed from those on $\mathrm{VO}_{x} / \mathrm{Al}_{2} \mathrm{O}_{3}$. The $1 \mathrm{CrAl}\left(0.6 \mathrm{Cr} \mathrm{nm}^{-2}\right)$ sample shows four bands at 1907, 1879, 1788, and $1733 \mathrm{~cm}^{-1}$ due to NO adsorption on $\mathrm{Al}_{2} \mathrm{O}_{3}$ (Figure 7a). Three weak bands at 1946, 1557 , and $1225 \mathrm{~cm}^{-1}$ were also detected in this sample. The bands for $\mathrm{NO}$ adsorbed on $\mathrm{Al}_{2} \mathrm{O}_{3}$ became weaker and the bands at 1946,1557 , and $1225 \mathrm{~cm}^{-1}$ strengthened with increasing $\mathrm{CrO}_{x}$ surface density. Concurrently, complex spectral features became evident in the region of $1900-1700 \mathrm{~cm}^{-1}$. The bands at 1557 and $1225 \mathrm{~cm}^{-1}$ have been attributed to the formation of nitrate species by the reaction of $\mathrm{Cr}^{6+}$ with $\mathrm{NO},{ }^{51,52}$ via the reaction
$\mathrm{Cr}^{6+}+\mathrm{NO}+2 \mathrm{O}^{2-} \rightarrow \mathrm{Cr}^{3+}+\mathrm{NO}_{3}^{-}$, which reduces $\mathrm{Cr}^{6+}$ to $\mathrm{Cr}^{3+}$ while oxidizing $\mathrm{N}^{2+}$ to $\mathrm{N}^{5+}$. The positions of these bands lead to their assignment to bidentate nitrates. The band at 1950$1930 \mathrm{~cm}^{-1}$ is attributed to $\mathrm{NO}^{+}$species. ${ }^{51}$ The bands at 1870 and $1750 \mathrm{~cm}^{-1}$ are assigned to $\mathrm{Cr}^{3+}(\mathrm{NO})_{2}$ species, as in the case of $\mathrm{NO}$ adsorbed on $\mathrm{CrO}_{x} / \mathrm{Al}_{2} \mathrm{O}_{3}$ treated with $\mathrm{H}_{2}$ at $673 \mathrm{~K}$ (not shown here). The band at $1781 \mathrm{~cm}^{-1}$ arises from $\mathrm{Cr}^{3+}$. (NO), ${ }^{53}$ and that at $1827 \mathrm{~cm}^{-1}$ arises from mononitrosyl species on $\mathrm{Cr}^{3+}$ or $\mathrm{Cr}^{2+} .53,54$ The integrated areas of the bands at 1557 and $1733 \mathrm{~cm}^{-1}$ are shown in Figure $7 \mathrm{~b}$ as a function of $\mathrm{CrO}_{x}$ surface density. The intensity of the band at $1733 \mathrm{~cm}^{-1}$ decreases with increasing $\mathrm{CrO}_{x}$ surface density, and the intensity of the band at $1557 \mathrm{~cm}^{-1}$ band increases concurrently.

Infrared spectra for $\mathrm{NO}$ adsorbed on $12 \mathrm{VAl}\left(6.5 \mathrm{~V} \mathrm{~nm}^{-2}\right)$, $12 \mathrm{CrAl}, 10 \mathrm{~V} 12 \mathrm{CrAl}\left(6.3 \mathrm{~V} \mathrm{~nm}^{-2}\right)$, and 12Cr10VAl samples treated in dry air at $773 \mathrm{~K}$ for $1 \mathrm{~h}$ are shown in Figure 8a. The infrared bands for $\mathrm{NO}$ dimers on $\mathrm{V}^{5+}$ and for $\mathrm{NO}_{3}{ }^{-}$species on $\mathrm{Cr}^{6+}$ are well-resolved on $10 \mathrm{~V} 12 \mathrm{CrAl}$ and $12 \mathrm{Cr} 10 \mathrm{VAl}$. Clearly, the bands at 1775 and $1683 \mathrm{~cm}^{-1}$ were stronger in the spectrum for $10 \mathrm{~V} 12 \mathrm{CrAl}$ than in that for $12 \mathrm{Cr} 10 \mathrm{VAl}$, but those at 1950 , 1555 , and $1225 \mathrm{~cm}^{-1}$ were more intense for $12 \mathrm{Cr} 10 \mathrm{VAl}$ than for $10 \mathrm{~V} 12 \mathrm{CrAl}$. The ratio of integrated intensities for the infrared bands at 1775 and $1555 \mathrm{~cm}^{-1}, I_{1775} / I_{1555}$, is 12.8 for $10 \mathrm{~V} 12 \mathrm{CrAl}$ but only 2.3 for $12 \mathrm{Cr} 10 \mathrm{VAl}$, suggesting that more $\mathrm{V}^{5+}$ sites are exposed when $\mathrm{VO}_{x}$ is deposited on $\mathrm{CrO}_{x}-\mathrm{Al}_{2} \mathrm{O}_{3}$ than when the deposition sequence is reversed. The deposition of $\mathrm{CrO}_{x}$ onto $\mathrm{VO}_{x}-\mathrm{Al}_{2} \mathrm{O}_{3}$ leads, in turn, to the preferential exposure of $\mathrm{Cr}$ species at surfaces. Thus, samples retain some surface preference for the species deposited last, even if thermal treatment causes some partial mixing within bilayers.

Figure $8 \mathrm{~b}$ shows infrared spectra for $\mathrm{NO}$ adsorbed on $x \operatorname{V12CrAl}\left(x=3-10,2.1-6.3 \mathrm{~V} \mathrm{~nm}^{-2}\right)$ treated in flowing dry air at $773 \mathrm{~K}$ for $1 \mathrm{~h}$. The bands at 1775 and $1683 \mathrm{~cm}^{-1}$ for NO dimers on $\mathrm{V}^{5+}$ increased with increasing $\mathrm{VO}_{x}$ surface density, while the nitrate bands at 1557 and $1225 \mathrm{~cm}^{-1}$ concurrently decreased, even though all samples contain similar amounts of $\mathrm{Cr}$. The intensities of the bands at $1683 \mathrm{~cm}^{-1}$ (NO dimers on $\mathrm{V}^{5+}$ ) and $1557 \mathrm{~cm}^{-1}$ (nitrates on $\mathrm{Cr}^{6+}$ ) are shown in Figure 8c as a function of the $\mathrm{VO}_{x}$ surface density. The band at $1557 \mathrm{~cm}^{-1}$ for nitrate species on $\mathrm{Cr}^{6+}$ decreased linearly, consistent with the decreasing fraction of $\mathrm{Cr}^{6+}$ inferred from spectroscopic and chemical analyses (e.g., Figure 5b). In contrast, the band at 1683 $\mathrm{cm}^{-1}$ for NO dimers on $\mathrm{V}^{5+}$ sites increased monotonically with increasing $\mathrm{VO}_{x}$ surface density.

The assumption that the surface of $\mathrm{Al}_{2} \mathrm{O}_{3}$ is entirely covered by $\mathrm{VO}_{x}$ species for $12 \mathrm{VAl}$, which contains a theoretical monolayer of polyvanadate species, and by $\mathrm{CrO}_{x}$ in $12 \mathrm{CrAl}$, which contains a theoretical monolayer of polychromate species, allows estimates of the percentage of the alumina surface covered by $\mathrm{V}^{5+}$ and $\mathrm{Cr}^{6+}$ in other samples. These estimates are obtained by comparing the integrated areas for the 1683 and $1557 \mathrm{~cm}^{-1}$ bands in each $x \mathrm{~V} 12 \mathrm{CrAl}$ sample with those for $12 \mathrm{VAl}$ and $12 \mathrm{CrAl}$ (Figure $8 \mathrm{c}$ ) and are reported in Table 3. Clearly, $\mathrm{CrO}_{x}$ species predominate on the surface of samples with a low $\mathrm{VO}_{x}$ surface density, while $\mathrm{VO}_{x}$ species become more abundant as the $\mathrm{VO}_{x}$ surface density increases.

$\mathrm{V}-\mathrm{O}-\mathrm{Cr}$ bands in the Raman spectra (Figure 1) indicate that $\mathrm{VO}_{x}$ and $\mathrm{CrO}_{x}$ mix in $\mathrm{VCrAl}$. For $10 \mathrm{~V} 12 \mathrm{CrAl}$, containing equivalent monolayers of both $\mathrm{CrO}_{x}$ and $\mathrm{VO}_{x}$, perfect mixing would lead to $\sim 50 \% \mathrm{VO}_{x}$ coverage on the alumina surface. Instead, we detect enrichment by $\mathrm{VO}_{x}\left(68 \% \mathrm{VO}_{x}\right.$, Table 3$)$, suggesting that mixing is incomplete and that the oxide deposited last remains preferentially exposed. On the basis of the $\mathrm{NO}$ adsorption data listed in Table 3 and the $\mathrm{VO}_{x}$ surface 

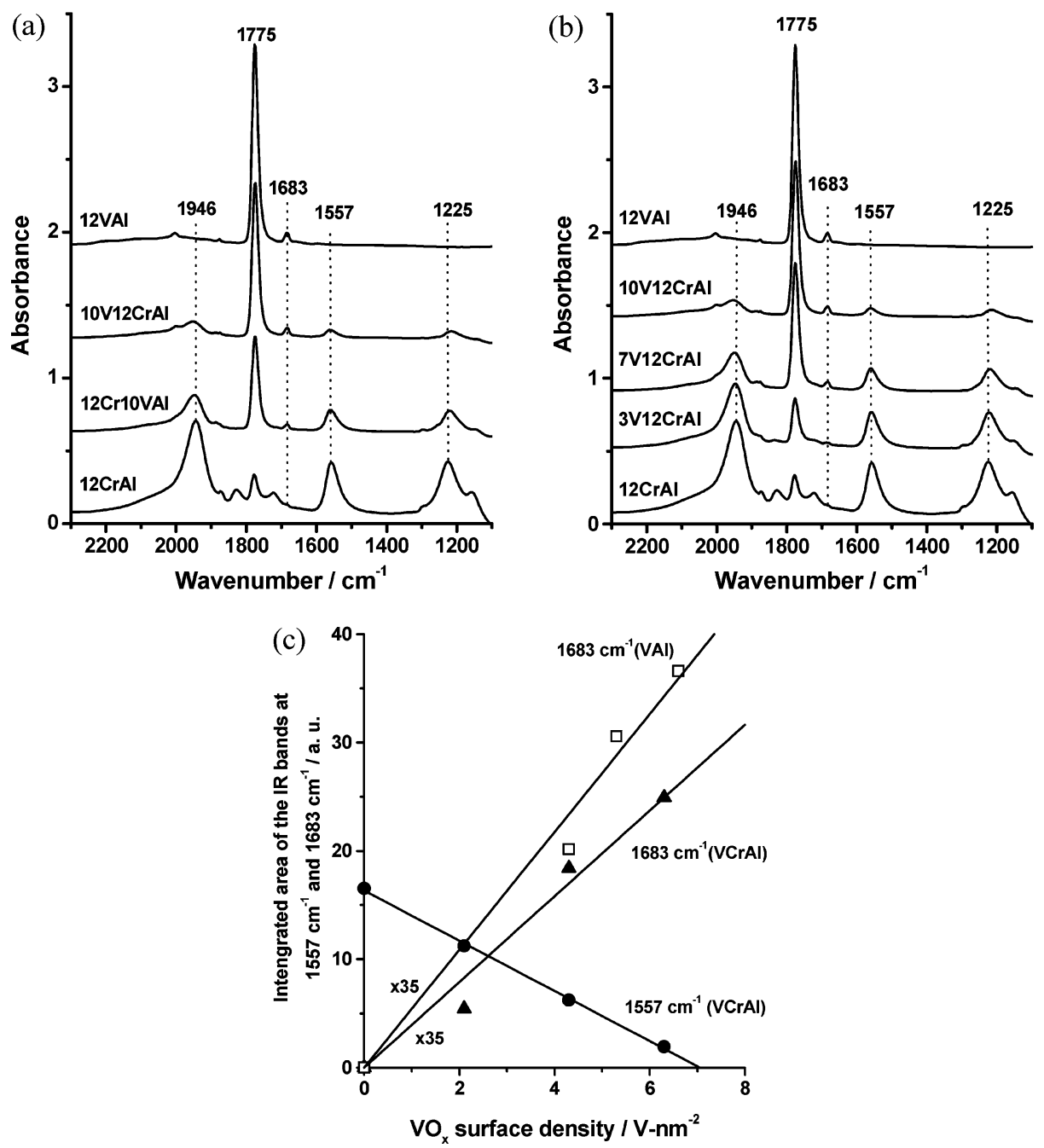

Figure 8. (a) IR spectra of $\mathrm{NO}$ adsorbed on oxidized $12 \mathrm{VAl}, 12 \mathrm{CrAl}, 10 \mathrm{~V} 12 \mathrm{CrAl}$, and $12 \mathrm{Cr} 10 \mathrm{VAl}$ treated in $\mathrm{O}_{2}(100 \mathrm{Torr})$ at $773 \mathrm{~K}$ for $1 \mathrm{~h}$. (b) IR spectra of $\mathrm{NO}$ adsorbed on oxidized $x \mathrm{~V} 12 \mathrm{CrAl}(x=3-10)$ treated in $\mathrm{O}_{2}(100$ Torr) at $773 \mathrm{~K}$ for $1 \mathrm{~h}$. (b) Integrated intensities of the IR bands at $1683 \mathrm{~cm}^{-1}$ (NO dimer on V site) and $1557 \mathrm{~cm}^{-1}$ (nitrate on $\mathrm{Cr}$ site) in part b as a function of $\mathrm{VO}_{x}$ surface density. For comparison, the integrated intensities of the IR bands at $1683 \mathrm{~cm}^{-1}$ for $10 \mathrm{VAl}$ and $12 \mathrm{VAl}$ samples are also shown.

TABLE 3: Percentage of Surface Exposed $\mathrm{VO}_{x}, \mathrm{Cr}^{6+}$, and $\mathrm{Cr}^{3+}$ on Different Catalysts Determined from IR and NO Adsorption Results

\begin{tabular}{lcccc}
\hline \multicolumn{1}{c}{ sample } & $\begin{array}{c}\text { surf covered } \\
\text { by } \mathrm{VO}_{x}\end{array}$ & $\begin{array}{c}\text { surf covered } \\
\text { by } \mathrm{Cr}^{6+}\end{array}$ & $\begin{array}{c}\text { surf covered } \\
\text { by } \mathrm{Cr}^{3+}\end{array}$ & $\begin{array}{c}\mathrm{VO}_{x} / \mathrm{CrO}_{x} \\
\text { mixing }\end{array}$ \\
\hline $12 \mathrm{CrAl}$ & & $60 \%$ & $40 \%$ & \\
$3 \mathrm{~V} 12 \mathrm{CrAl}$ & $15 \%$ & $41 \%$ & $44 \%$ & $\sim 35 \%$ \\
$7 \mathrm{~V} 12 \mathrm{CrAl}$ & $50 \%$ & $23 \%$ & $27 \%$ & $\sim 33 \%$ \\
$10 \mathrm{~V} 12 \mathrm{CrAl}$ & $68 \%$ & $7 \%$ & $25 \%$ & $\sim 64 \%$ \\
$12 \mathrm{VAl}$ & $100 \%$ & & &
\end{tabular}

densities given in Table 1 and assuming that only $50 \% \mathrm{VO}_{x}$ will be accessed by $\mathrm{NO}$ if $\mathrm{VO}_{x}$ mixes with $\mathrm{CrO}_{x}$ to form a mixed compound like $\mathrm{CrVO}_{4}$, the extents of $\mathrm{VO}_{x} / \mathrm{CrO}_{x}$ mixing for $3 \mathrm{~V} 12 \mathrm{CrAl}, 7 \mathrm{~V} 12 \mathrm{CrAl}$, and $10 \mathrm{~V} 12 \mathrm{CrAl}$ are estimated to be $\sim 35 \%, \sim 33 \%$, and $\sim 64 \%$, respectively.

The rates and primary selectivities for oxidative dehydrogenation of propane on $12 \mathrm{CrAl}, 12 \mathrm{VAl}, 10 \mathrm{~V} 12 \mathrm{CrAl}$, and
12Cr10VAl are compared in Table 4, which also shows the percentages of the surface covered by $\mathrm{V}^{5+}$ and $\mathrm{Cr}^{6+} / \mathrm{Cr}^{3+}$. The last two catalysts, similar in composition and in Raman and $\mathrm{X}$-ray absorption spectra, give very different $\mathrm{ODH}$ rates and selectivities. ODH rates on $10 \mathrm{~V} 12 \mathrm{CrAl}$ are $\sim 50 \%$ higher than on $12 \mathrm{Cr} 10 \mathrm{VAl}$, and $10 \mathrm{~V} 12 \mathrm{CrAl}$ also gives higher primary $\mathrm{ODH}$ selectivities. These observations reflect a higher accessibility of $\mathrm{VO}_{x}$, which has a higher primary selectivity, at the surface of $10 \mathrm{~V} 12 \mathrm{CrAl}$. Reactions of $\mathrm{VO}_{x}$ with $\mathrm{CrO}_{x}$ to form a mixed oxide, such as $\mathrm{CrVO}_{4}$, lead to higher ODH rates and to lower propane combustion selectvities. Indeed, $12 \mathrm{CrAl}$, which contains the highest fraction of $\mathrm{Cr}^{6+}$, also gives the lowest primary $\mathrm{ODH}$ selectivity.

\section{Conclusions}

Samples of $\mathrm{CrAl}$ undergo autoreduction of $\mathrm{CrO}_{x}$ species during calcination, resulting in the appearance of $\mathrm{Cr}^{3+}$ cations.

TABLE 4: Percentage of Surface Exposed $\mathrm{VO}_{x}, \mathrm{Cr}^{6+}$, and $\mathrm{Cr}^{3+}$ on Different Catalysts Determined from IR and NO Adsorption Results and Their Propane ODH Rates and Selectivity at $583 \mathrm{~K}$

\begin{tabular}{|c|c|c|c|c|c|}
\hline sample & $\begin{array}{l}\text { surf covered } \\
\text { by } \mathrm{VO}_{\mathrm{x}}\end{array}$ & $\begin{array}{l}\text { surf covered } \\
\text { by } \mathrm{Cr}^{6+}\end{array}$ & $\begin{array}{l}\text { surf covered } \\
\text { by } \mathrm{Cr}^{3+}\end{array}$ & $\begin{array}{c}\text { primary formation rate of } \\
\mathrm{C}_{3} \mathrm{H}_{6} \text { at } 583 \mathrm{~K}\left(\mu \mathrm{mol} \mathrm{g} \mathrm{g}^{-1} \mathrm{~s}^{-1}\right)\end{array}$ & $\begin{array}{c}\text { primary } \mathrm{C}_{3} \mathrm{H}_{6} \\
\text { selectivity at } 583 \mathrm{~K}\end{array}$ \\
\hline $12 \mathrm{CrAl}$ & & $60 \%$ & $40 \%$ & 0.68 & $34 \%$ \\
\hline $12 \mathrm{VAl}$ & $100 \%$ & & & 0.89 & $93 \%$ \\
\hline $10 \mathrm{~V} 12 \mathrm{CrAl}$ & $68 \%$ & $7 \%$ & $25 \%$ & 1.13 & $87 \%$ \\
\hline $12 \mathrm{Cr} 10 \mathrm{VAl}$ & $37 \%$ & $23 \%$ & $40 \%$ & 0.76 & $39 \%$ \\
\hline
\end{tabular}


In the case of $\mathrm{VCrAl}, \mathrm{VO}_{x}$ reacts with $\mathrm{CrO}_{x}$ to form $\mathrm{CrVO}_{4}$, thereby facilitating the reduction of $\mathrm{Cr}^{6+}$ to $\mathrm{Cr}^{3+}$. With increasing $\mathrm{VO}_{x}$ surface density, the amount of $\mathrm{Cr}^{6+}$ in $\mathrm{VCrAl}$ decreases monotonically. $\mathrm{NO}$ is a good probe for distinguishing between $\mathrm{V}$ and $\mathrm{Cr}$ sites at the surface of the binary oxide. Antisymmetric ONON dimers are formed on $\mathrm{V}^{5+}$, and nitrate species are formed on $\mathrm{Cr}^{6+}$, while dinitrosyls are formed on $\mathrm{Cr}^{3+}$. These species have bands at different frequencies, and as a result, surface exposed $\mathrm{V}$ and $\mathrm{Cr}$ sites could be identified. Partial mixing of $\mathrm{VO}_{x}$ with $\mathrm{CrO}_{x}$ was demonstrated by $\mathrm{NO}$ adsorption. Examination of $\mathrm{NO}$ adsorption on $\mathrm{VCrAl}$ samples by altering the sequence of $\mathrm{VO}_{x}$ and $\mathrm{CrO}_{x}$ deposition suggests that binary dispersed $\mathrm{VCr}$ catalysts have a memory of the last deposited species. Thus, $\mathrm{VO}_{x} / \mathrm{CrO}_{x} / \mathrm{Al}_{2} \mathrm{O}_{3}$ exhibits an enhancement in the $\mathrm{VO}_{x}$ present at the surface of the binary oxide relative to $\mathrm{CrO}_{x} / \mathrm{VO}_{x} / \mathrm{Al}_{2} \mathrm{O}_{3}$, and the latter sample exhibits an enhancement in $\mathrm{CrO}_{x}$ relative to the former sample. The catalytic activity and selectivity of $\mathrm{VCr}$ binary oxide catalysts is also dependent on the order in which the oxides are deposited. The $\mathrm{ODH}$ activity and propene selectivity of $\mathrm{VO}_{x} / \mathrm{CrO}_{x} / \mathrm{Al}_{2} \mathrm{O}_{3}$ are noticeably higher than those of $\mathrm{CrO}_{x} / \mathrm{VO}_{x} / \mathrm{Al}_{2} \mathrm{O}_{3}$, reflecting the differences in the surface composition of the two types of catalysts. The formation of $\mathrm{CrVO}_{4}$ appears to enhance catalyst activity relative to $\mathrm{VO}_{x}$ alone, and the minimization of $\mathrm{Cr}^{6+}$ at the catalyst contributes to the attainment of a high primary selectivity to propene.

Acknowledgment. This work was supported by the Director, Office of Basic Energy Sciences, Chemical Sciences Division of the US Department of Energy under Contract DE-AC0376SF00098. X-ray absorption data were collected at the Stanford Synchrotron Radiation Laboratory, which is operated by the Department of Energy, Office of Basic Energy Sciences, under Contract DE-AC02-05CH11231. We thank Prof. Kazunari Domen and Dr. Junko N. Kondo of the Tokyo Institute of Technology for providing us with the low-temperature infrared cell used for this study.

\section{References and Notes}

(1) Kung, H. H. Adv. Catal. 1994, 40, 1.

(2) Albonetti, S.; Cavani, F.; Trifiro, F. Catal. Rev.-Sci. Eng. 1996, $38,413$.

(3) Cavani, F.; Koutyrev, M.; Trifiro, F.; Bartolini, A.; Ghisletti, D.; Iezzi, R.; Santucci, A.; Del Piero, G. J. Catal. 1996, 158, 236.

(4) Blasko, T.; López Nieto, J. M. Appl. Catal., A 1997, 157, 117.

(5) Khodakov, A.; Yang, J.; Su, S.; Iglesia, E.; Bell, A. T. J. Catal.

1998, 177, 343 .

(6) Khodakov, A.; Olthof, B.; Bell, A. T.; Iglesia, E. J. Catal. 1999, $181,205$.

(7) Chen, K.; Khodakov, A.; Yang, J.; Bell, A. T.; Iglesia, E. J. Catal. 1999, 186,325 .

(8) Chen, K.; Bell, A. T.; Iglesia, E. J. Phys. Chem. B 2000, 104, 1292.

(9) Olthof, B.; Khodakov, A.; Bell, A. T.; Iglesia, E. J. Phys. Chem. B 2000, 104, 1516 .

(10) Chen, K.; Iglesia, E.; Bell, A. T. J. Catal. 2000, 192, 197.

(11) Argyle, M. D.; Chen, K.; Bell, A. T.; Iglesia, E. J. Catal. 2002, 208, 139.

(12) Chen, K.; Bell, A. T.; Iglesia, E. J. Catal. 2002, 209, 35.

(13) Garcia Cortez, G.; Fierro, J. L. G.; Banares, M. A. Catal. Today 2003, 78, 219 .
(14) Grabowski, R.; Sloczynski, J.; Grzesik, N. M. Appl. Catal., A 2003 , 242, 297.

(15) Cherian, M.; Gupta, R.; Rao, M. S.; Deo, G. Catal. Lett. 2003, 86, 179.

(16) Cherian, M.; Rao, M. S.; Deo, G. Catal. Today 2003, 78, 397.

(17) Jibril, B. Y.; Al-Zahrani, S. M.; Abasaeed, A. E.; Hughes, R. Catal. Commun. 2003, 4, 579 .

(18) Jibril, B. Y.; Al-Zahrani, S. M.; Abasaeed, A. E.; Hughes, R. Catal. Lett. 2003, 3-4, 121

(19) Al-Zahrani, S. M.; Jibril, B. Y.; Abasaeed, A. E. Catal. Lett. 2003, 85,57 .

(20) Jibril, B. Y. Appl. Catal. A 2004, 264, 193.

(21) Routray, K.; Reddy, K. R. S. K.; Deo, G. Appl. Catal., A 2004 265,103 .

(22) Ballarini, N.; Cavani, F.; Cericola, A.; Cortelli, C.; Ferrari, M.; Trifiro, F.; Capannelli, G.; Comite, A.; Catani, R.; Cornaro, U. Catal. Today 2004, 91-92, 99.

(23) Grabowski, R. Appl. Catal., A 2004, 270, 37.

(24) De, M.; Kunzru, D. Catal. Lett. 2004, 96, 33

(25) Pieck, C. L.; Banares, M. A.; Fierro, J. L. G. J. Catal. 2004, 224,

(26) Dai, H.; Bell, A. T.; Iglesia, E. J. Catal. 2004, 221, 491.

(27) Yang, S.; Bell, A. T.; Iglesia, E. J. Phys. Chem. B 2005, 109, 8987.

(28) Touboul, M.; Melghit, K. J. Mater. Chem. 1995, 5, 147.

(29) Baudrin, E.; Denis, S.; Orsini, F.; Seguin, L.; Touboul, M.; Tarascon, J.-M. J. Mater. Chem. 1999, 9, 101

(30) Vuurman, M. A.; Wachs, I. E. J. Phys. Chem. 1992, 96, 5008.

(31) Yang, G.; Haibo, Z.; Biying, Z. J. Mater. Sci. 2000, 35, 917.

(32) Weckhuysen, B. W.; Wachs, I. E.; Schoonheydt, R. A. Chem. Rev. 1996, 96, 3327.

(33) Deo, G.; Wachs, I. E. J. Phys. Chem. 1991, 95, 5889.

(34) Vuurman, M. A.; Stufkens, D. J.; Oskam, A.; Moulijn, J. A.; Kapteijn, F. J. Mol. Catal. 1990, 60, 83.

(35) Owen, O. S.; Kung, H. H. J. Mol. Catal. 1993, 79, 265.

(36) Briand, L. E.; Jehng, J.-M.; Cornaglia, L; Hirt, A. M.; Wachs, I.

E. Catal. Today 2003, 78, 257

(37) Baran, E. J. J. Mater. Sci. 1998, 33, 2479

(38) Baudrin, E.; Denis, S.; Orsini, F.; Seguin, L.; Touboul, M.; Tarascon, J.-M. J. Mater. Chem. 1999, 9, 101.

(39) Song, Z.; Matsushita, T.; Shishido, T.; Takehira, K. J. Catal. 2003, 218,32

(40) Zhang, S. G.; Higashimoto, S.; Yamashita, H.; Anpo, M. J. Phys. Chem. B 1998, 102, 5590 .

(41) Anpo, M.; Zhang, S. G.; Higashimoto, S.; Matsuoka, M.; Yamashita, H. J. Phys. Chem. B 1999, 103, 9295.

(42) Bordiga, S.; Bosherini, F.; Coluccia, S.; Genoni, F.; Lamberti, C.; Leofanti, G.; Marcheses, L.; Petrini, G.; Vlaic, G.; Zecchina, A. Catal. Lett. 1994, 26, 195.

(43) Weckhuysen, B. M.; Schoonheydt, R. A.; Jehng, J.-M.; Wachs, I. E.; Cho, S. J.; Ryoo, R.; Kijlstra, S.; Poels, E. J. Chem. Soc., Faraday Trans. 1995, 91, 3245 .

(44) Grzybowska, B.; Sloczynski, J.; Grabowski, R.; Wcislo, K.; Kozlowska, A.; Stoch, J.; Zielinski, J. J. Catal. 1998, 178, 687.

(45) Davydov, A. In IR Spectroscopy of Adsorbed Species on the Surface of Transition Metal Oxides; Rochester, C. H., Ed.; Wiley: Chichester, 1990.

(46) Davydov, A. Kinet. Catal. 1993, 34, 1056.

(47) Dines, T. J.; Rochester, C. H.; Ward, A. M. J. Chem. Soc., Faraday Trans. 1991, 87, 1617

(48) Davydov, A. Russ. Chem. Bull. 1994, 43, 214.

(49) Laane, J.; Ohlsen, J. R. Prog. Inorg. Chem. 1986, $28,465$.

(50) Hadjiivanov, K.; Concepción, P.; Knözinger, H. Top. Catal. 2000, $11-12,123$.

(51) Mihaylov, M.; Penkova, A.; Hadjiivanov, K.; Knözinger, H. J. Phys Chem. B 2004, 108, 679 .

(52) Schraml-Marth, M.; Wokaun, A.; Baiker, A. J. Catal. 1992, 138, 306.

(53) Ghiotti, G.; Chiorino, A. Spectrochim. Acta 1993, 49A, 1345.

(54) Ghiotti, G.; Garrone, E,; Gatta G. D.; Fubini, B.; Giamello, E. J. Catal. 1983, $80,249$. 